\title{
Tsunami Hazard Assessment of the Black Sea Coast in the Regions of the Planned Coming Out of the Russia-Turkey Gas Pipelines
}

\author{
L.I. Lobkovsky¹, R.Kh. Mazova',*, I.V. Remizov² \\ ${ }^{1}$ P.P. Shirshov Institute of Oceanology, RAS, Moscow, Russian Federation \\ ${ }^{2}$ R.E. Alekseev Nizhny Novgorod State Technical University, Nizhny Novgorod, Russian Federation \\ *e-mail: raissamazova@yandex.ru
}

\begin{abstract}
The results of numerical simulation of tsunami waves in the Black Sea basin are represented for assessing possible tsunami hazards for the coastal zone in the points where the planned underwater parts of the Russia-Turkey gas pipelines ("Turkish Stream” and "Blue Stream - 2") enter the sea and come out to the coast. Numerical simulation of the tsunami source generation and tsunami wave propagation in the Black Sea is carried out in two scenarios for 7 seismic sources. To assess potential tsunami hazard, each of the performed calculations implies modeling of the seismic sources in the basin regions (with due regard to the character of their geodynamic faults and structures) where the pipelines can possibly come out to the coast. Synthetic tide gauges along the coastline are used to analyze the results of the calculations. The simulation is done within the framework of the earthquake key-board model which takes into account the zones of active faults. For each model, the characteristics of the wave fields and the direction of the most intense propagation of the wave fronts are obtained and analyzed at the selected time points. The tsunami wave maximum heights are estimated for the places where the gas pipelines come out to the coast and enter the sea both on the Russian and Turkish coasts. It is shown that at moderate earthquakes, hazard of tsunami wave impact upon laying the gas pipelines along the considered directions is insignificant. At the same time, at stronger earthquakes, the danger of the coastal infrastructure destruction is real. Thus, the drawn conclusion implies strong necessity in the detailed tsunami zonation of the coast and marking out the local sections where the planned gas pipelines enter the sea and come out to the coast.
\end{abstract}

Keywords: tsunami, seismic and tsunami hazard, tsunamigenic earthquakes, tsunami waves, numerical simulation, the Black Sea coast

DOI: 10.22449/1573-160X-2017-3-77-90

(C) 2017, L.I. Lobkovsky, R.Kh. Mazova, I.V. Remizov

(C) 2017, Physical Oceanography

\section{Introduction}

Seismic and tsunami hazard assessment of the Black Sea (both Russian and other coasts of the given basin) is one of the most important problems tasks of the last decades. Great attention to this issue was paid in the works of Sergey Dotsenko (for example, [1-13]), in which the characteristics of the Black Sea tsunami were studied and possible features of generated tsunami wave propagation in the open water area and the northwestern part of the sea were assessed. In these works, the role of residual displacements of the Black Sea bottom in tsunami generation was studied and dispersion effects during the generation were analyzed. A number of studies of great practical importance were also carried out, for instance, the ways to protect the infrastructure of coastal areas and underwater structures, including securing the laying and operation of offshore gas pipelines in the area of underwater slope sections, where these pipelines go to land. 
The timeliness of these calculations is associated with increased seismicity and a landslide hazard of a number of the Black Sea coasts [13-17]. These factors cause increased risks of exploitation of the Russian-Turkish gas pipeline offshore section (the Blue Stream project), connecting the territories of the two countries along the Black Sea bottom and operating under such risks [18]. In Fig. 1 the yellow arrows indicate the motion of lithospheric plates, creating stresses in the fault area [16, 17 and 19]. Regional fault tectonics determines the high tsunamigenicity of the region, which gradually increases from the west to east along the Black Sea basin and the surrounding regions.

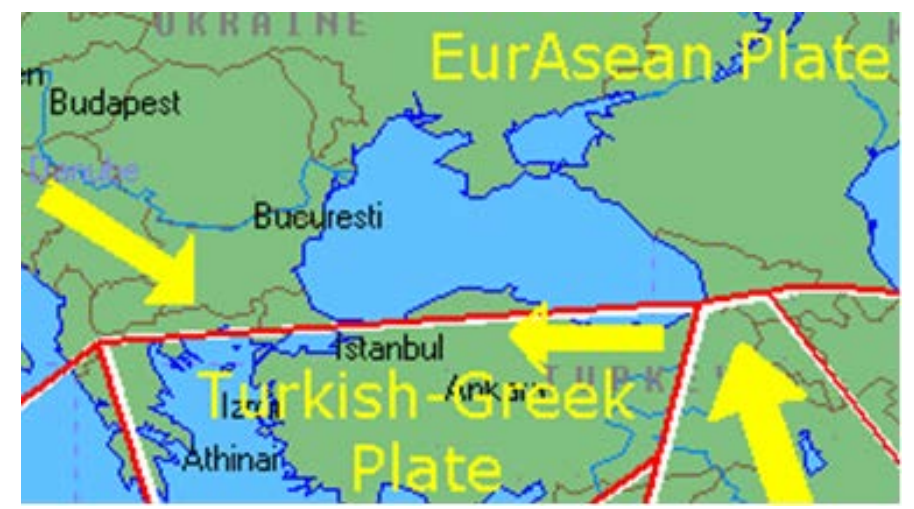

Fig. 1. Map of the faults along the Black Sea basin and the surrounding regions [16, 17 and 19]

Numerical simulation of tsunami wave propagation in the open part of the Black Sea was carried out in a number of works (for example, [1, 7, 10, 11, 20-25]. The forecast for the wave heights at the coast was also given.

In works [20-22] the Black Sea coast tsunami zonation (up to a 5-meter isobath) was performed for a number of scenarios of underwater earthquakes with the most probable potential seismic sources.

The present work presents the results of calculations for specific sections of the coast, where variants of constructing terminals for new gas transmission systems passing along the Black Sea bottom (with a new project, the Russian-Turkish gas pipeline Turkish Stream) are considered.

In the first of the planned laying scenarios, the underwater pipeline for $660 \mathrm{~km}$ coincides with the corridor of the previously planned South Stream project. Then it passes $250 \mathrm{~km}$ along a new corridor to the Turkish coast and goes on land near Kiyiköy. From the Russian side, the offshore terminal of the gas pipeline is located on the Black Sea coast near Russkaya compressor station near Anapa.

In accordance to the second scenario, the Turkish land section begins in the Samsun district with a terminal with the Durusu gas metering station. The Russian land section ends with Beregovaya compressor station in the area of Dzhubga village, Krasnodar Krai on the Black Sea coast [18]. 
Based on the data on zones of active faults and geodynamic features of the main structures of various sections of the Black Sea coast [16, 17 and 19], the position of potential seismic sources was determined. Fig. 2 shows the route of the construction of a possible new Russian-Turkish gas pipeline Turkish Stream [26, 27] (Scenario 1).

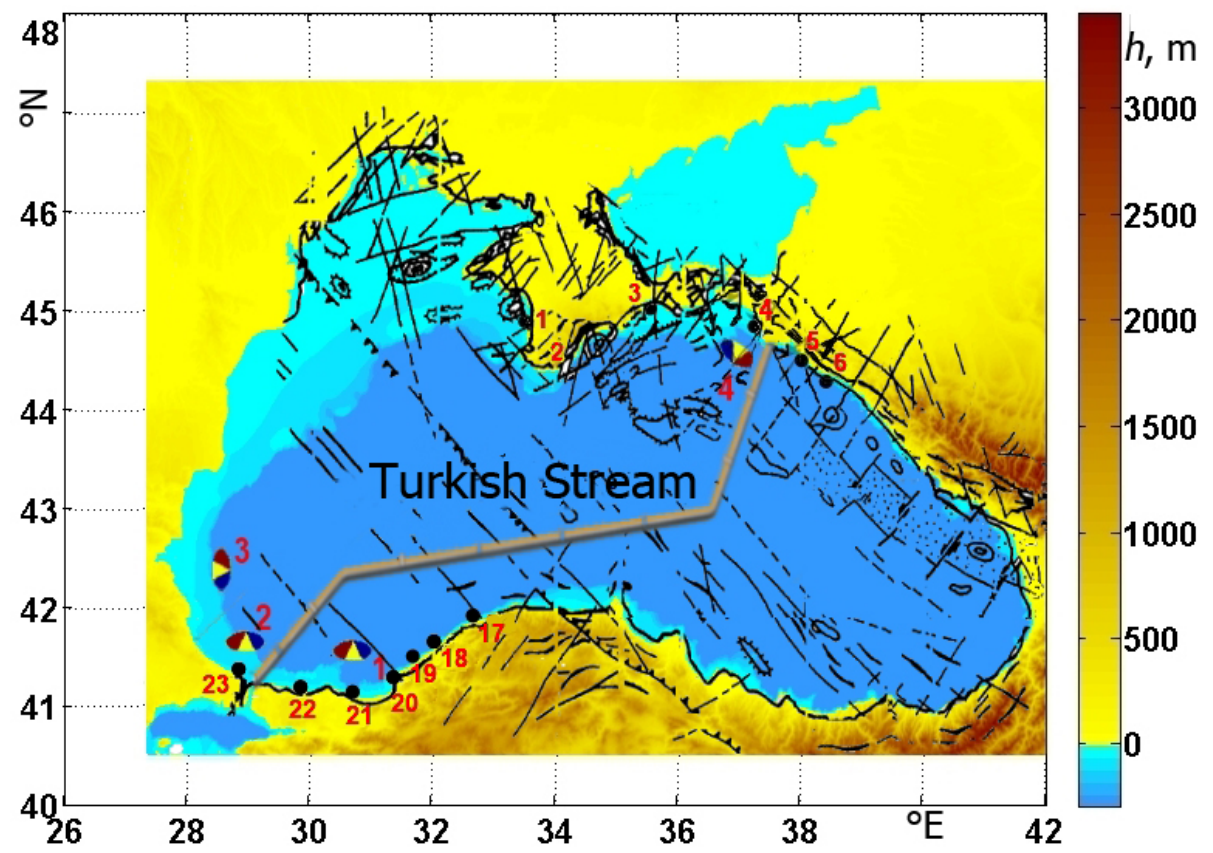

Fig. 2. The model route of the Turkish Stream gas pipeline (Scenario 1) [26, 27]

In the areas of gas pipeline offshore section exit and entrance, the seismic centers are located on the coast: from the Turkish side - at numbers 1, 2 and 3, and from the Russian side - the source 4 located near Anapa. There are synthetic tide gauges on the 5-meter isobath: 1-6 along the Russian coast, 17-23 along the Turkish one.

Fig. 3 shows the route of a possible land-sea variant of the new Blue Stream-2, which leaves Beregovaya station and enters the Samsun point on the Turkish coast (Scenario 2). There are the following seismic centers calculated in the areas of gas pipeline exit and entrance on the coast: from the Turkish side -6 and 7 and from the Russian side - the source 5. Along the Russian coast there are synthetic tide gauges 4-9, along the Turkish one $-10-16$. It can be seen that the sources for Scenario 2 are oriented in the same way as for Scenario 1. This location of the sources corresponds to the typical character of the faults and structures of various sections of the Black Sea coast [16, 17 and 19]. 


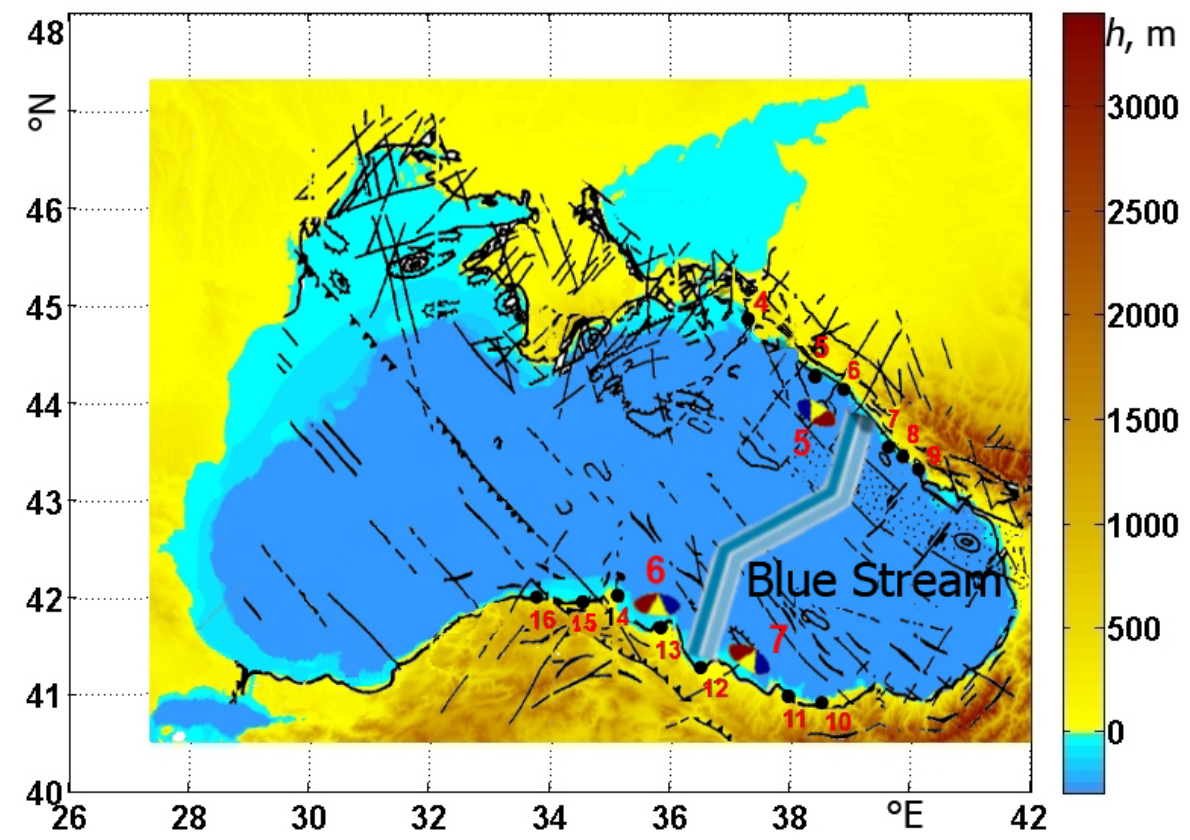

Fig. 3. The route of the new Blue Stream-2 gas pipeline (Scenario 2) [26, 27]

The simulation was carried out for a strong earthquake with a magnitude of $M=7.0$, since the probability of tsunami wave occurrence at such a value of $M$ is quite large $(P=0.81$ [28]).

The results of calculation of two variants for each scenario are given in this work. To estimate the initial parameters of tsunami waves, which can be generated by a seismic source, the known formulas for coupling earthquake magnitude and characteristic parameters of faults in the interplate boundary in the subduction zone, developed for tectonically active regions of the globe, were used. These parameters determining the seismic source include: the length of the fault in the source, its width and the possible height of the vertical displacement of the sea bottom in the source [28]. Knowing the mechanism of the source or specifying it from tectonic considerations [29] and using the Wells [28] and Iida (see, e.g. [30]) formulas, it is possible to calculate the vertical component of the residual bottom displacement in the source and use this value to simulate generation of the tsunami waves.

Based on the data from [1, 5, 7, 21 and 22], the seismic sources of an ellipsoidal shape (Fig. 4) divided into three parts (so-called keyboard blocks) were considered in the present paper.

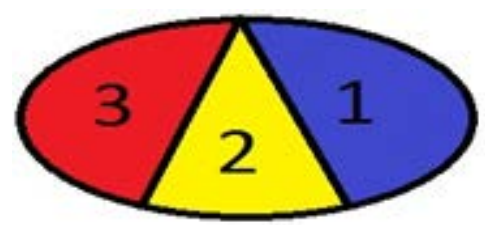

Fig. 4. Model geometry of a seismic source

According to the pattern of typical fault zones [16, 17 and 19] and characteristic realization of keyboard block motions in seismic sources in the limited water areas [20-22], the order of block motion in the seismic sources given in Tab. 1 was selected. It should be emphasized that the keyboard blocks in the present scheme move independently, sequentially, one after another. 
For the first variant of the calculations, at the earthquake magnitude $M=7,0$, the block 1 moves vertically downwards by $1.5 \mathrm{~m}$ in $30 \mathrm{~s}$, then the block 2 moves vertically upward by $2.1 \mathrm{~m}$ in $10 \mathrm{~s}$ and after it stops the block 3 moves vertically upward by $1.8 \mathrm{~m}$ in $10 \mathrm{~s}$. The block motion scheme for all the sources shown in Fig. 1 and Fig. 2 is the same. For the second variant of the calculations at the earthquake magnitude $M=7.3$, the motion of the blocks has the similar order; the parameters are set in Tab. 1.

T able 1

Motion of the Blocks in the Seismic Source for Two Variants of Calculation

\begin{tabular}{c|c|c|c}
\hline \multirow{2}{*}{$\begin{array}{c}\text { No. } \\
\text { (from right to } \\
\text { left) }\end{array}$} & Motion time, s & \multicolumn{2}{|c}{ Vertical displacement $\Delta h, \mathrm{~m}$} \\
\cline { 3 - 4 } & & at $M=7.0$ & at $M=7.3$ \\
\hline 1 & 30 & -1.5 & -2.0 \\
2 & 10 & 2.1 & 3.0 \\
3 & 10 & 1.8 & 3.9 \\
\hline
\end{tabular}

In the present work, the results of four calculations are presented for four seismic sources as an example. Two of these sources (1 and 2) are located in the region of the entry of the Turkish Stream pipeline on the coast of Turkey (Scenario 1 (see Fig. 1)), while the other two (sources 6 and 7) - in the area of the new Blue Stream-2 pipeline entry to the Turkish coast (Scenario 2 (see Fig. 2)). Detailed calculations are given only for a strong earthquake with a magnitude $M=7.0$.

\section{Numerical simulation of a possible earthquake and tsunami}

The simulation was carried out applying a software package (see, for example, [21]), developed on the Sielecki scheme basis [31]. A 200 s time step satisfying the Courant condition was used in the simulation. In the coastal zone on an isobath equal to $5 \mathrm{~m}$, the boundary conditions (vertical wall approach) were used in the last nodes of the computational grid.

To analyze the tsunami wave generation process within the keyboard model of a seismic source and their propagation in the basin, the equations of the theory of shallow water in a nonlinear setting are used (see, e.g. [20-22, 30]). To take into account the seismic source dynamics, the spatio-temporal function $\varphi(x, y$ and $t)$ is introduced. Depending on the problem statement, the blocks in the source can move sequentially with a certain time delay (or without it) with different initial velocities. Since the formation of the tsunami source will be a time function, the dynamics of this process in the seismic source will determine the formation of wave fronts propagating from the tsunami source. The process of propagation of these waves and their interaction is considered taking into account the real bathymetry.

\section{Scenario 1: the Turkish Stream}

Fig. 5-8 shows the results of numerical simulation for Scenario 1 (source 1). In Fig. 5 the position of the wave fronts at six time moments in this calculation can be seen. The wave front, moving to the southeast, quickly reaches the Turkish coast 
in the area of the gas pipeline exit to the land. Then, spreading through the deep water to the northwest, the front reaches the offshore section of the gas pipeline exit to the Russian coast. Estimates suggest the tsunami propagation time in the water area from the southern (source 1) to the Russian coast (Yalta) to be $3600 \mathrm{~s}$.

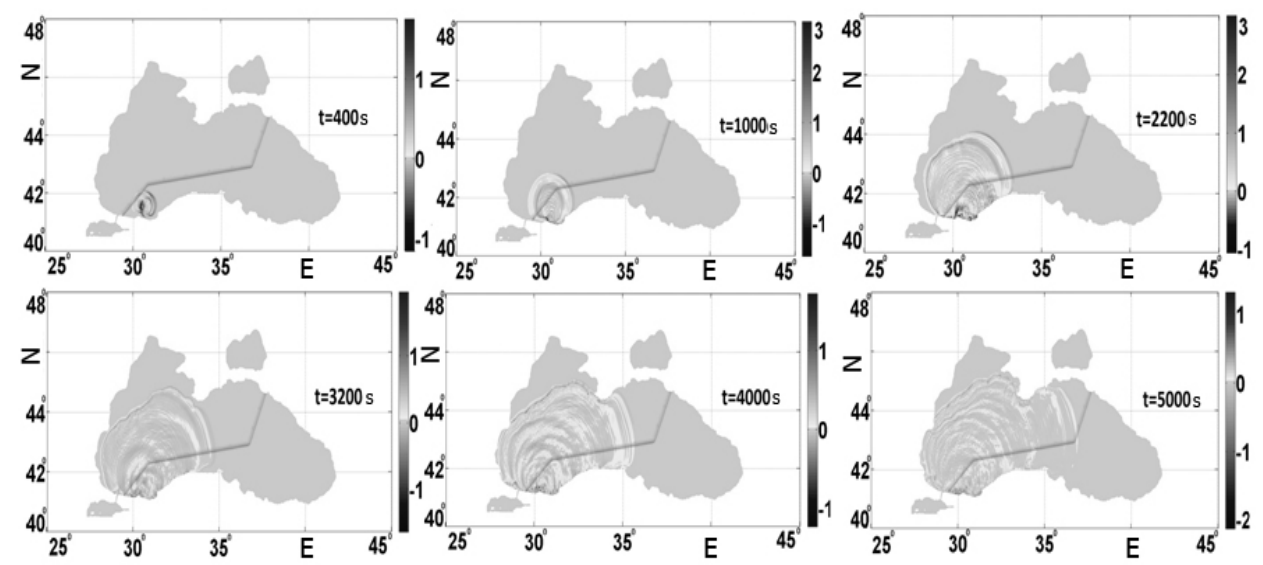

Fig. 5. The position of the wave fronts at the realization of Scenario 1 (source 1) for six time moments
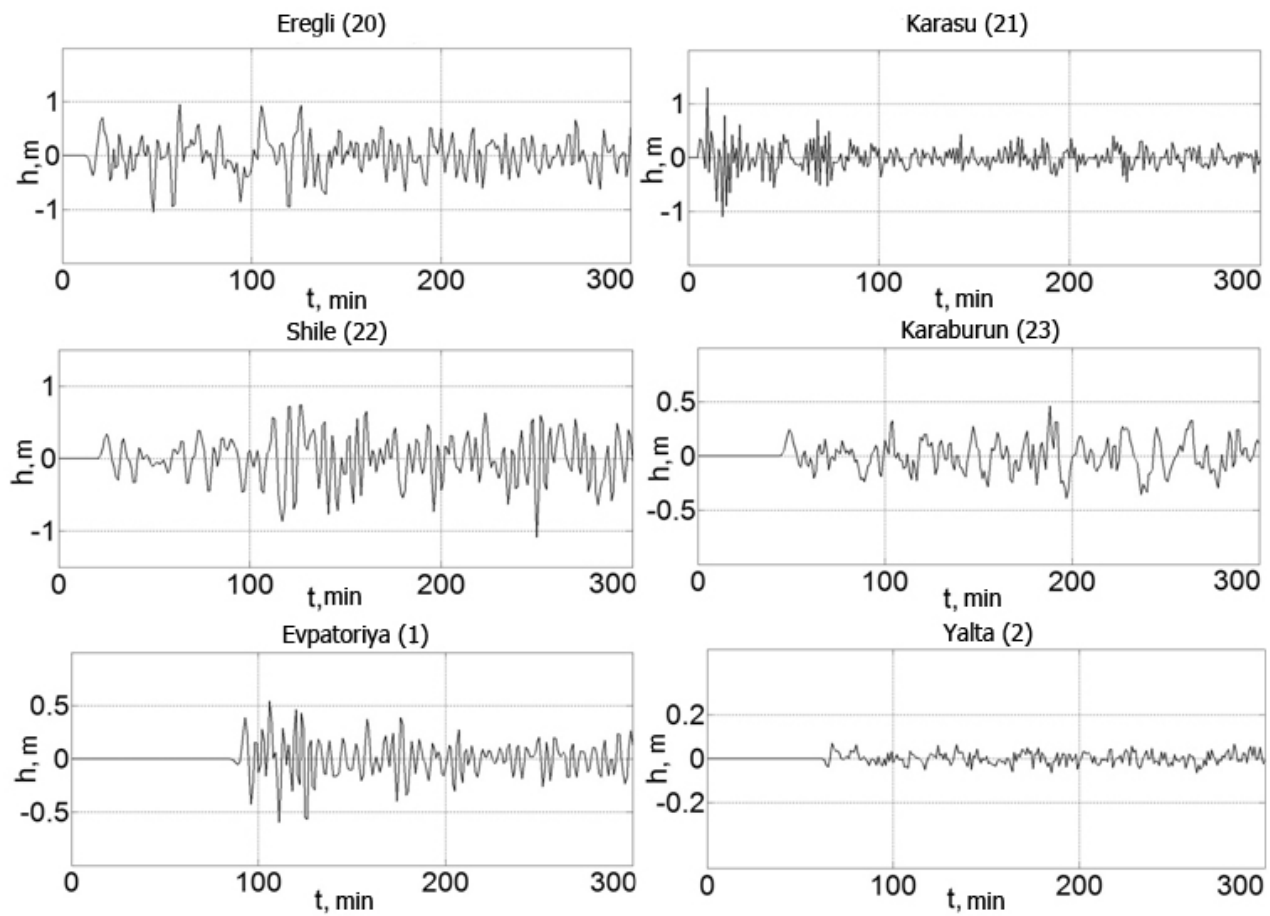

Fig. 6. Synthetic tide gauge records at the realization of Scenario 1 (source 1): 20-23 points - on the Turkish coast, 1 and 2 - on the Russian one 
Analysis of the tide gauge records (Fig. 6), obtained from synthetic tide gauges, showed that the maximum wave heights in the interval $28-32^{\circ} \mathrm{E}$ range from $10 \mathrm{~cm}$ to $1 \mathrm{~m}$. It is clearly seen that, depending on the realization of the motion of the blocks in the seismic source, in the direction to the coast the waves will be approached either by a positive phase (by the wave crest) in points 21, 22 and 23 or by a negative phase (by water withdrawal from shore) in points 20,1 and 2 . On the Turkish coast, the wave height reaches its maximum value of $1.2 \mathrm{~m}$ (at point 21) and decreases to $0.3 \mathrm{~m}$ approaching the point of the gas pipeline exit to land (in point 23). The greatest frequency of water level fluctuations is observed in point 21 . On the Russian coast of maximum height $(0.5 \mathrm{~m})$ the reached wave reaches at point 1 , while in point 2 the amplitude of water level oscillations is only $0.1 \mathrm{~m}$. It can be noted that the frequency of water level oscillations in point 1 is much higher than in point 2, which may be due to the shelf zone peculiarities in each of the sections.

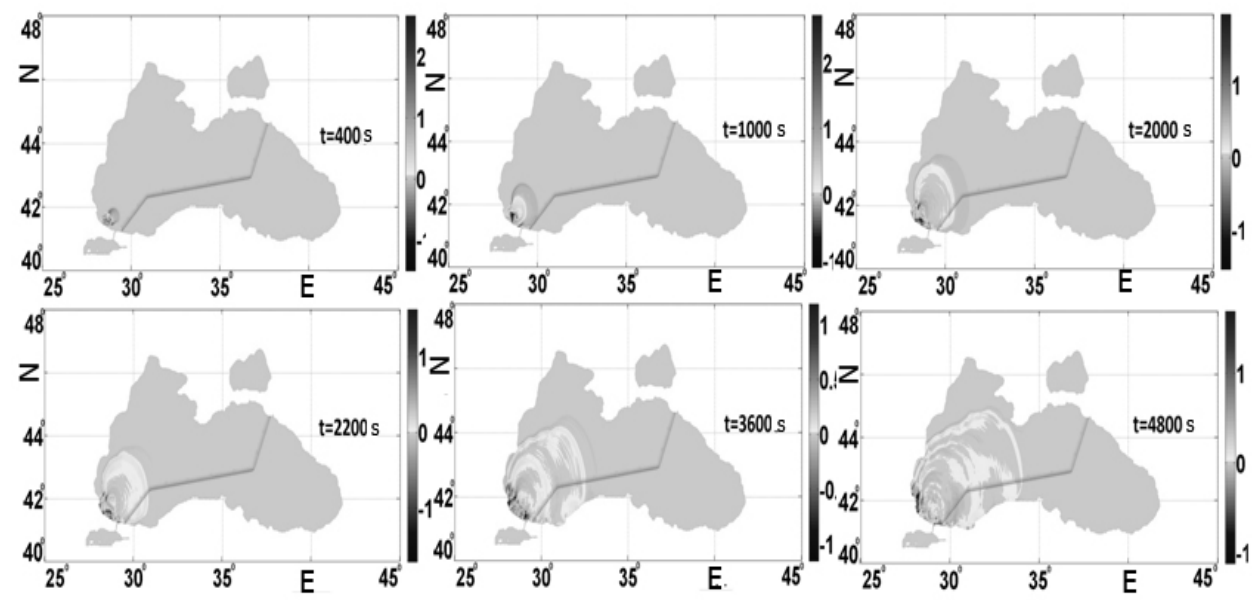

Fig. 7. The position of the wave fronts at the realization of Scenario 1 (source 2) for six time moments
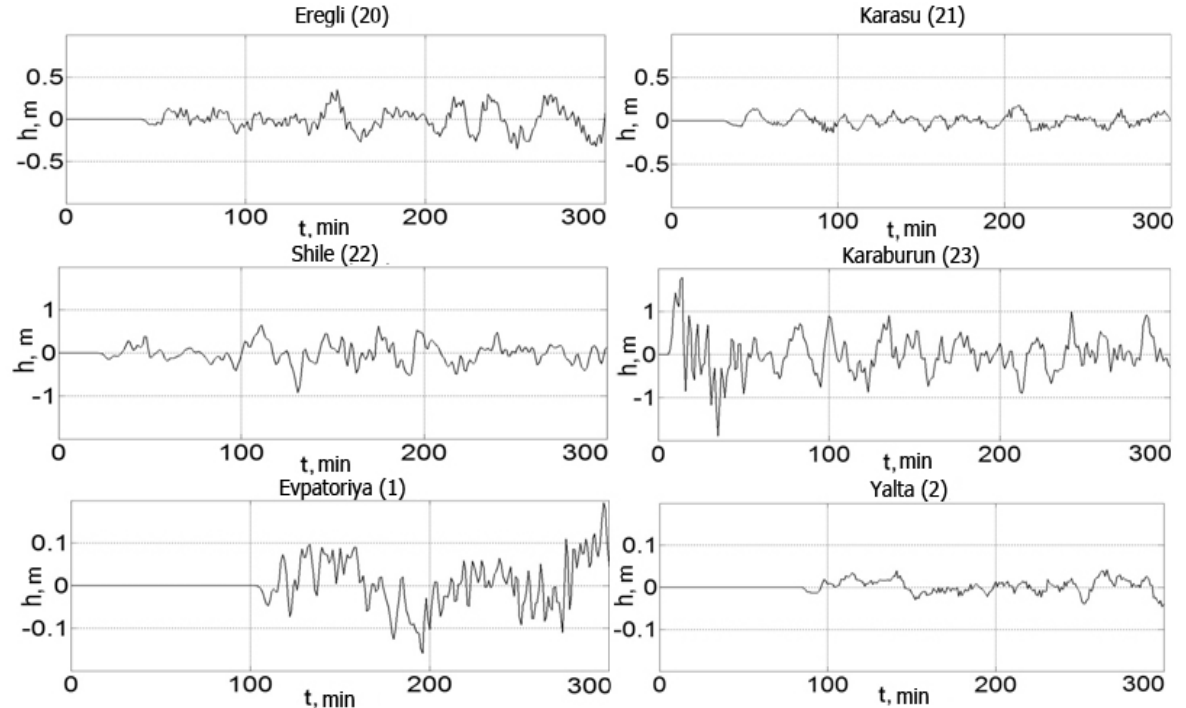

Fig. 8. Synthetic tide gauge records at the realization of Scenario 1 (source 2): 20-23 points - on the Turkish coast, 1 and 2 - on the Russian one

PHYSICAL OCEANOGRAPHY NO.3 (2017) 
For the same Scenario 1, the localization of the seismic source 2 to the west of the planned gas pipeline route is considered (see Fig. 2). From Fig. 7 it can be clearly seen that to the place where the offshore section of the gas pipeline starts on the opposite shore, the wave will approach for over 5000 s. Fig. 8 shows the synthetic tide gauge records for Scenario 1 (source 2) at $M=7.0$ at four points on the southwestern coast of Turkey (20-23) and two on the Russian coast (1 and 2). In points 20, 21 and 22 the wave approaches the coast with a slight decrease in the level. In point 23, a relatively large height $(1.8 \mathrm{~m})$ of the first crest and a greater frequency of water level oscillations can be noted. On the Russian coast (points 1,2 ) the waves come with a maximum height of $0.1 \mathrm{~m}$.

\section{Scenario 2: new "Blue Stream - 2"}

The results of numerical modeling for the source 6 (see Fig. 3) are represented in Fig. 9-12.

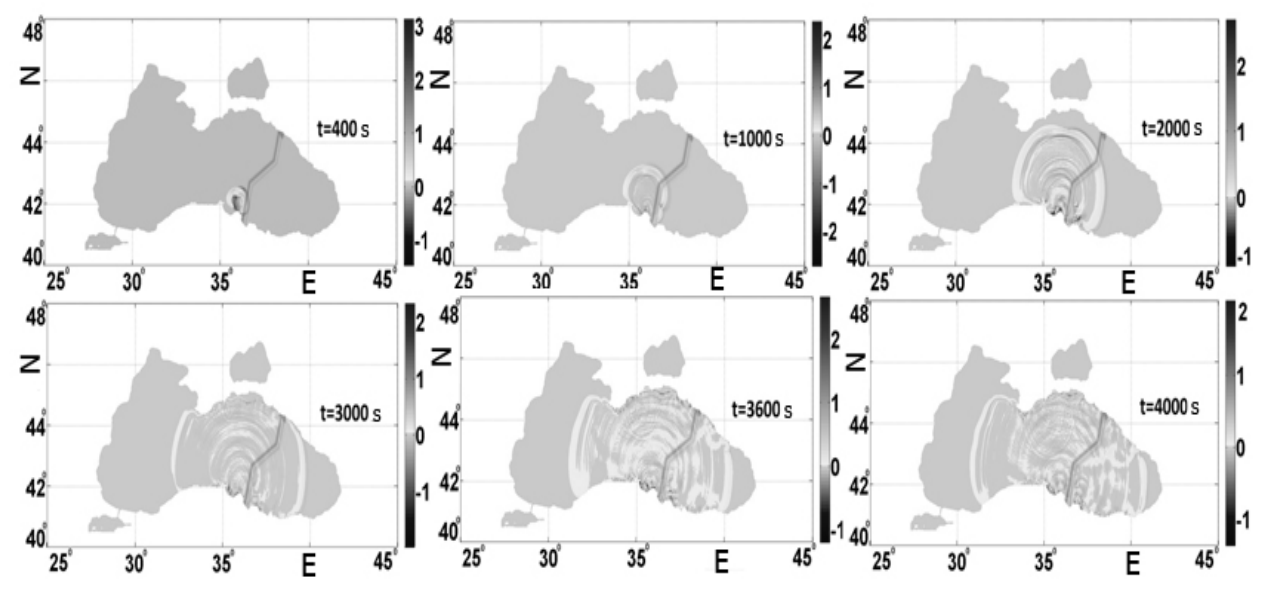

Fig. 9. The position of the wave fronts at the realization of Scenario 2 (source 6) for six time moments

Fig. 12 shows synthetic tide gauge records for the source 7 at $M=7.0$ earthquake magnitude at four points near the Turkish coast in the northwest of the Black Sea (points 10-12) and at two points in the northeast near the Russian coast (points 6 and 7). It can be clearly seen that in points $6,7,10,11$ the wave approaches the coast with a negative phase (rundown), in two points (12 and 13) the first wave is positive (wave crest).

The height of the waves at the Turkish coast near the place where Turkish gas pipeline terminal is located reaches $70 \mathrm{~cm}$, at the Russian coast - up to $40 \mathrm{~cm}$. The smallest wave level oscillation amplitude $(\sim 0.2 \mathrm{~m})$ is observed in points 10 and 13, while in points 11 and 12 (Samsun) the amplitude of the fluctuations reaches $1 \mathrm{~m}$. In point 12, in contrast to other points, against the background of relatively high-frequency level oscillations, an additional low-frequency modulation (carrier modulation) is observed in the tide gauge record. Such tide gauge record behavior may be caused by bathymetry geometric features in the shelf zone area 
around point 12. At the Russian coast in the points 6 and 7 the amplitude of oscillations in the tide gauge record is about $0.6 \mathrm{~m}$.
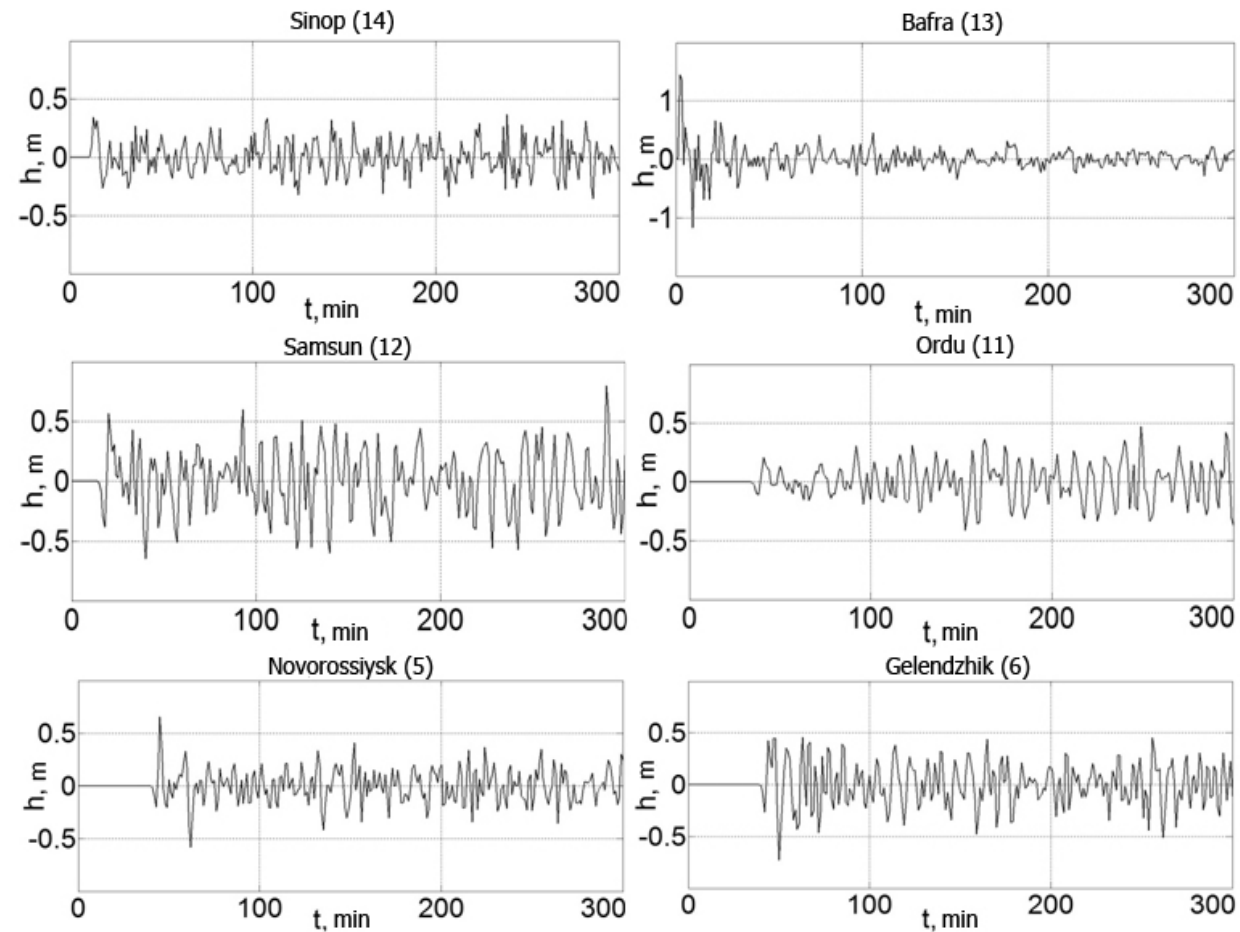

Fig. 10. Synthetic tide gauge records at the realization of Scenario 2 (source 2): 11-14 points - on the Turkish coast, 5 and 6 - on the Russian one

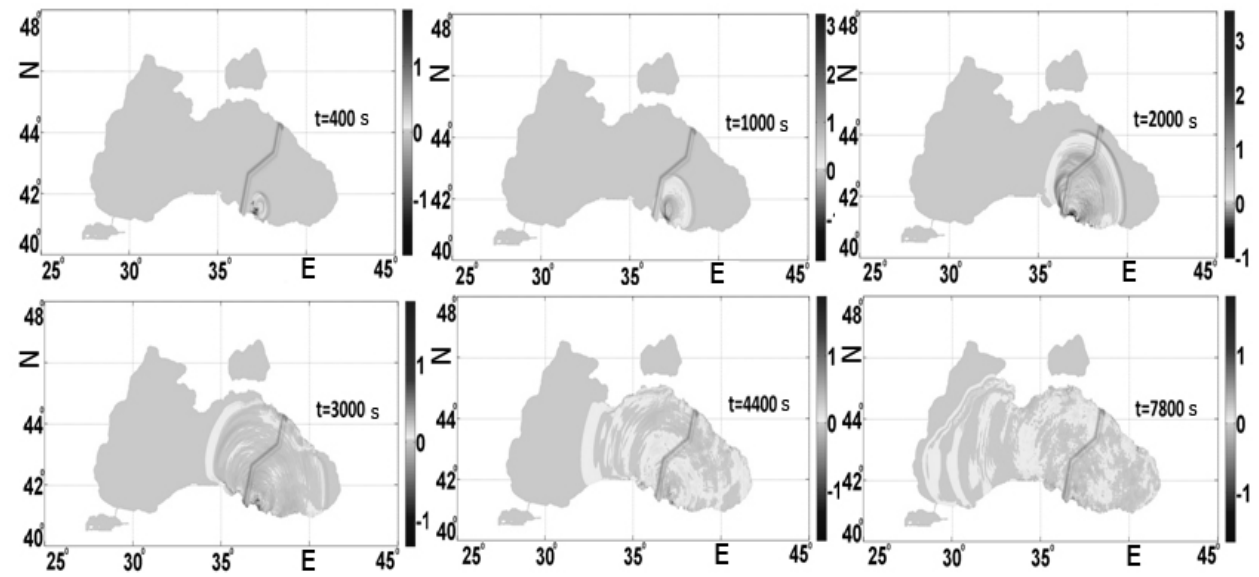

Fig. 11. The position of the wave fronts at the realization of Scenario 2 (source 7) for six time moments

PHYSICAL OCEANOGRAPHY NO.3 (2017) 
The obtained conclusions are represented more clearly in Fig. 13, where the maximum distributions of wave heights calculated according to the Scenarios 1 and 2 are given. It follows from the figure that the ranges of values of the maximum water raise both near the Turkish coast and near the Russian one lay within up to $2 \mathrm{~m}$ interval. It also should be pointed out that the greatest wave heights are localized rather far from possible regions where of the pipeline comes out onshore.
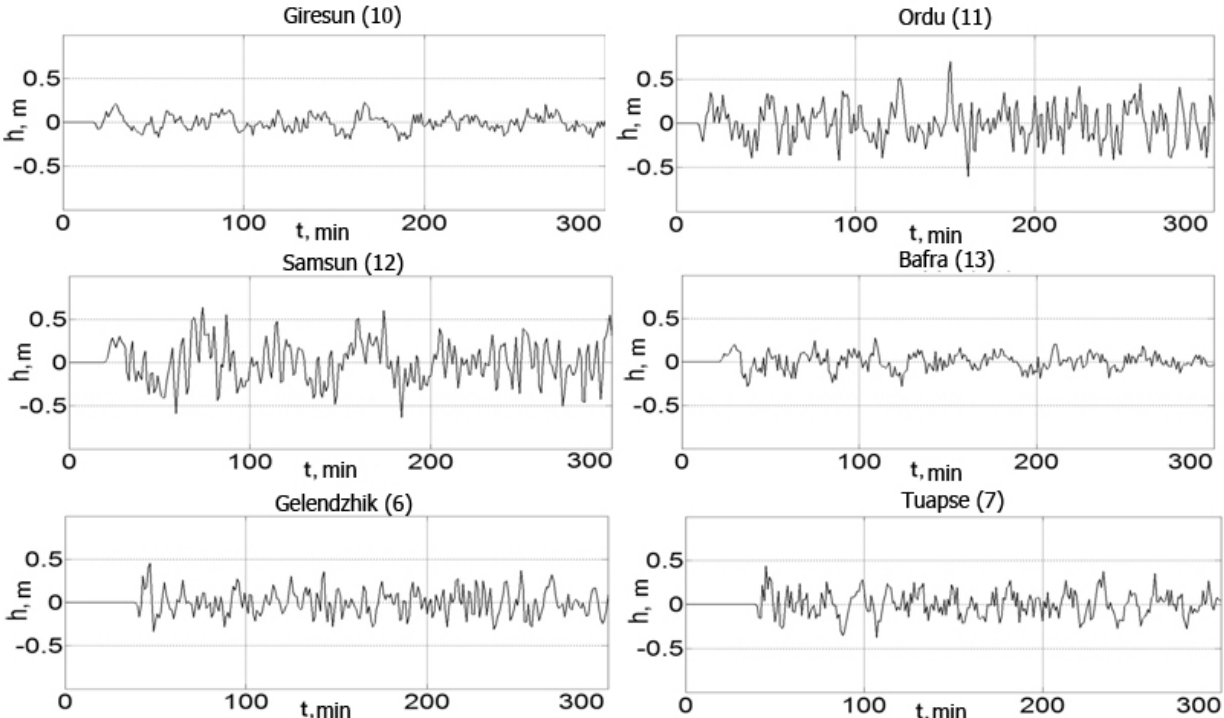

Fig. 12. Synthetic tide gauge records at the realization of Scenario 2 (source 7): 10-13 points - on the Turkish coast, 5 and 6 - on the Russian one

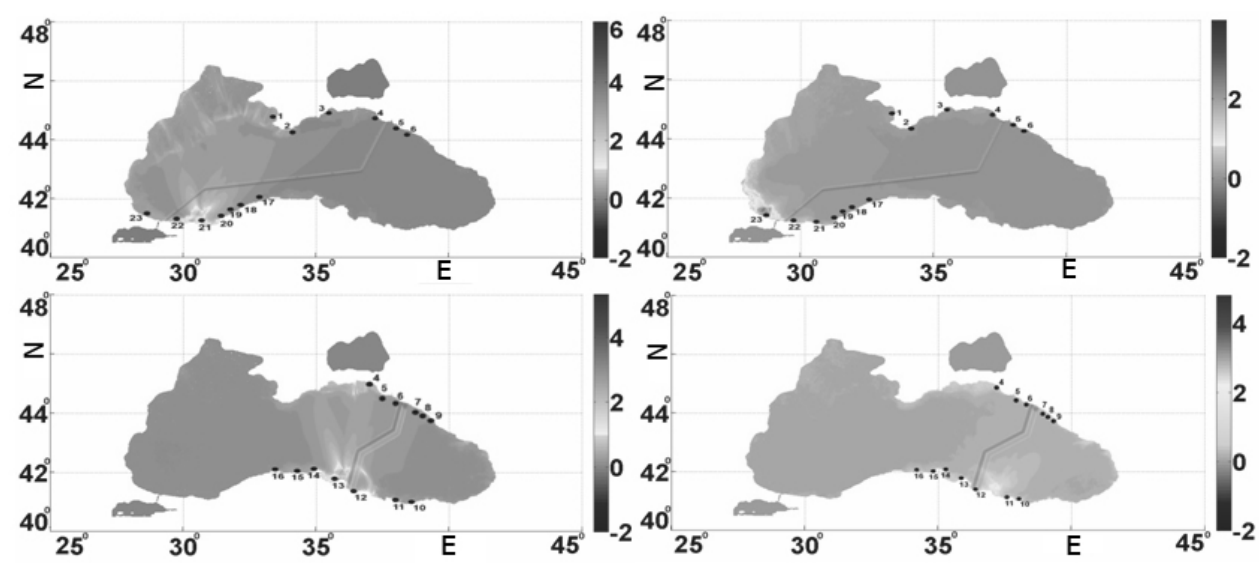

Fig. 13. The distribution of maximum wave heights propagating from the sources 1, 2 and 6,7 for the scenarios 1 and 2 (positions of synthetic tide gauges are denoted by the dots)

Thus, in Fig. 1-13 the data on computation of wave fields for massive earthquakes with $M=7.0$ magnitude are given. Similar calculations were also performed for seismic sources with the same localization at $M=7.3$ value. In Tables 2-5 the comparative data of the maximum wave heights at $M=7.0$ and 
$M=7.3$ magnitudes in certain points along the Turkish and Russian coasts, where the positions of synthetic tide gauge records were fixed, are given.

Table 2

\section{Comparative data of the maximum wave heights (Scenario 1, source 1)}

\begin{tabular}{c|c|c}
\hline $\begin{array}{c}\text { Tide } \\
\text { gauge } \\
\text { No. }\end{array}$ & $\begin{array}{c}\text { Maximum } \\
\text { height, m } \\
\text { (at } M=7 \text { ) }\end{array}$ & $\begin{array}{c}\text { Maximum } \\
\text { height, m } \\
\text { (at } M=7.3 \text { ) }\end{array}$ \\
\hline 20 & 0.98 & 2.60 \\
21 & 1.20 & 2.90 \\
22 & 0.75 & 1.80 \\
23 & 0.47 & 0.80 \\
1 & 0.56 & 0.90 \\
2 & 0.08 & 0.21 \\
\hline
\end{tabular}

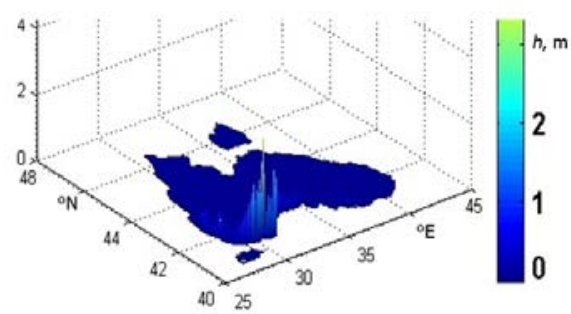

Fig. 14. Histogram for the source 1 at $M=7$ (according to the Scenario 1 )

T able 3

\section{Comparative data of the maximum wave heights (Scenario 1, source 2)}

\begin{tabular}{c|c|c}
\hline $\begin{array}{c}\text { Tide gauge } \\
\text { No. }\end{array}$ & $\begin{array}{c}\text { Maximum } \\
\text { height, } \mathrm{m} \\
\text { (at } M=7 \text { ) }\end{array}$ & $\begin{array}{c}\text { Maximum } \\
\text { height, m } \\
\text { (at } M=7.3 \text { ) }\end{array}$ \\
\hline 20 & 0.30 & 1.30 \\
21 & 0.20 & 0.51 \\
22 & 0.70 & 1.50 \\
23 & 1.80 & 3.80 \\
1 & 0.19 & 0.60 \\
2 & 0.04 & 0.13 \\
\hline
\end{tabular}

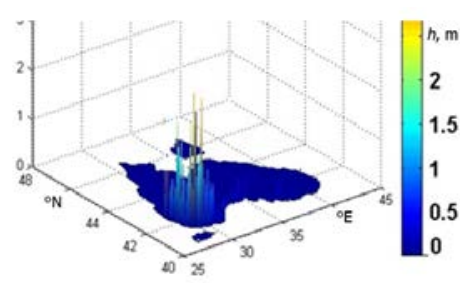

Fig. 15. Histogram for the source 2 at $M=7$ (according to the Scenario 1)

Table 4

Comparative data of the maximum wave heights (Scenario 2, source 6)

\begin{tabular}{c|c|c}
\hline $\begin{array}{c}\text { Tide gauge } \\
\text { No. }\end{array}$ & $\begin{array}{c}\text { Maximum } \\
\text { height, } \mathrm{m} \\
\text { (at } M=7 \text { ) }\end{array}$ & $\begin{array}{c}\text { Maximum } \\
\text { height, } \mathrm{m} \\
\text { (at } M=7.3 \text { ) }\end{array}$ \\
\hline 14 & 0.35 & 1.2 \\
13 & 1.43 & 2.2 \\
12 & 0.70 & 1.5 \\
11 & 0.47 & 1.0 \\
5 & 0.65 & 1.4 \\
6 & 0.48 & 1.8 \\
\hline
\end{tabular}

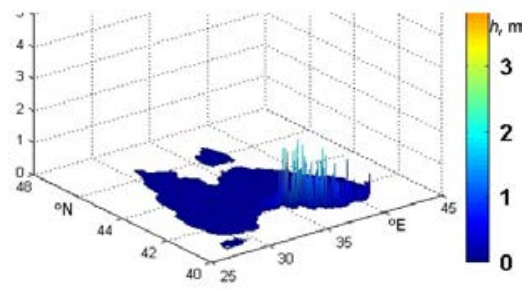

Fig. 16. Histogram for the source 6 at $M=7$ (according to the Scenario 2)

PHYSICAL OCEANOGRAPHY NO.3 (2017) 


\section{Comparative data of the maximum wave heights (Scenario 2, source 7)}

\begin{tabular}{c|c|c}
\hline $\begin{array}{c}\text { Tide gauge } \\
\text { No. }\end{array}$ & $\begin{array}{c}\text { Maximum } \\
\text { height, } \mathrm{m} \\
\text { (at } M=7 \text { ) }\end{array}$ & $\begin{array}{c}\text { Maximum } \\
\text { height, } \mathrm{m} \\
\text { (at } M=7.3 \text { ) }\end{array}$ \\
\hline 13 & 0.23 & 0.71 \\
12 & 0.74 & 1.84 \\
11 & 0.68 & 1.23 \\
10 & 0.27 & 0.68 \\
6 & 0.50 & 1.22 \\
7 & 0.35 & 0.77 \\
\hline
\end{tabular}

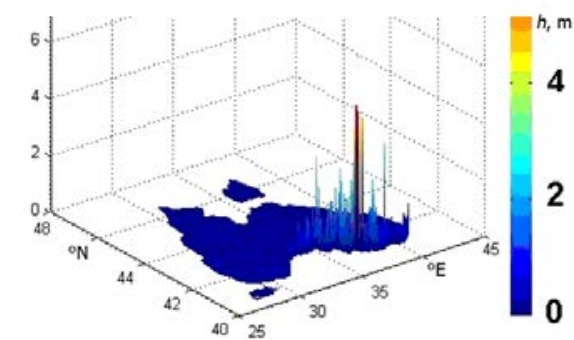

Fig. 17. Histogram for the source 7 at $M=7$ (according to the Scenario 2)

However, as it can be seen from the histograms in Fig. 14-17, at the sites which are the nearest to the selected points the values of the maximum heights may slightly differ. This can be easily explained by the physical effects, as well as by the geometry of the coastal zone. For instance, near the point 12 (Samsun) (where the result of calculation of the maximum wave height is $0.74 \mathrm{~m}$ ) the maximum heights reach $2 \mathrm{~m}$ (See Fig. 17).

\section{Conclusion}

Thus, it can be clearly seen that in those areas where the gas pipelines enter the sea and come out to the coast as well as in the places where the terminals with gas measuring stations are located the maximum wave heights (assessed for the massive earthquakes with magnitude value of 7) usually do not exceed $1 \mathrm{~m}$ (see Table 2-5). At some points of these regions wave height can reach the maximum value of up to $2 \mathrm{~m}$. At more massive earthquake (for instance, according to Scenario 2 at $M=7.3$ magnitude) in the areas where gas pipeline comes out onshore, wave height can reach (at some points) $4 \mathrm{~m}$. However, it should be taken into account that the calculation was carried out for $5 \mathrm{~m}$ isobath only. One may assume that a coastal slope will make an additional contribution to the height increase of a wave (which comes ashore) and this should be taken into account when designing a gas pipeline.

\section{Acknowledgements}

The work was carried out with a financial support from Russian Science Foundation (RSF) (the project No. 14-50-00095).

\section{REFERENCES}

1. Dotsenko, S.F., 1994. Chernomorskie Tsunami [The Black Sea Tsunami]. Izvestiya. Atmospheric and Oceanic Physics, 30(4), pp. 513-519 (in Russian).

2. Solov'eva, O.N., Dotsenko, S.F., Kuzin, I.P. and Levin, B.V., 2004. Tsunami v Chernom More: Istoricheskie Sobytiya, Seysmicheskie Istochniki i Zakonomernosti Rasprostraneniya [Tsunami in the Black Sea: Historical Events, Seismic Sources and Propagation Patterns]. Oceanology, 44(5), pp. 679-685 (in Russian). 
3. Dotsenko, S.F., Sergeevskiy, B.Yu. and Cherkesov, L.V., 1987. Generatsiya Prostranstvennykh Voln Tsunami Podvizhkami dna Konechnoy Prodolzhitel'nosti [Generation of Tsunami Spatial Waves by Finite Duration Bottom Movements]. In: Issledovaniya Tsunami № 2 [Study of Tsunami No. 2]. Moscow: Nauka, pp. 27-34 (in Russian).

4. Dotsenko, S.F. and Sergeevskiy, B.Yu., 1993. Dispersionnye Effekty pri Generatsii i Rasprostranenii Napravlennoy Volny Tsunami [Dispersive Effects in the Generation and Propagation of a Directional Tsunami Wave]. In: Issledovaniya Tsunami № 5 [Study of Tsunami No. 5]. Moscow: MGFK RAN, pp. 21-32 (in Russian).

5. Dotsenko, S.F. and Solov'ev, S.L., 1995. O Roli Ostatochnykh Smeshcheniy Dna Okeana v Generatsii Tsunami Podvodnymi Zemletryaseniyami [On the Role of Residual Displacements of the Ocean Bottom in the Tsunami Generation by Underwater Earthquakes]. Oceanology, 35(1), pp. 25-31 (in Russian).

6. Dotsenko, S.F. and Konovalov, A.V., 1996. Tsunami Waves in the Black Sea in 1927: Observations and Numerical Modelling. Physical Oceanography, [e-journal] 7(6), pp. 389-401. doi:10.1007/BF02509653

7. Dotsenko, S.F. and Konovalov, A.V., 1996. Numerical Modelling of Tsunami Propagation in the Open Black Sea. Physical Oceanography, [e-journal] 7(1), pp. 65-77. doi:10.1007/BF02509826

8. Dotsenko, S.F., 1996. Radiation of Long Waves from Black Sea Seismic Zones. Physical Oceanography, [e-journal] 7(5), pp. 315-320. doi:10.1007/BF02509868

9. Dotsenko, S.F., 2000. Relationship between the Intensity of Tsunami and the Location of the Epicentre of Underwater Earthquakes near the Continental Slope of the South Coast of Crimea. Physical Oceanography, [e-journal] 11(2), pp. 109-115. doi:10.1007/BF02515298

10. Dotsenko, S.F., 2005. Evaluation of the Parameters of Tsunami Waves along the South Coast of the Crimean Peninsula. Physical Oceanography, [e-journal] 15 (3), pp. 133-141. doi:10.1007/s11110-005-0036-z

11. Dotsenko, S.F., 2005. Specific Features of the Propagation of Tsunamis in the Northwest Part of the Black Sea. Physical Oceanography, [e-journal] 15(6), pp. 363-369. doi:10.1007/s11110-006-0009-x

12. Dotsenko, S.F. and Ingerov, A.V., 2007. Characteristics of Tsunami Waves in the Black Sea according to the Data of Measurements. Physical Oceanography, [e-journal] 17(1), pp. 17-28. doi:10.1007/s11110-007-0002-z

13. Solov'eva, O.N., Dotsenko, S.F., Kuzin, I.P. and Levin, B.V., 2004. Tsunami in the Black Sea: Historical Events, Seismic Sources and Features of Propagation. Oceanology, 44(5), pp. 638-643.

14. Solov'eva, O.N. and Kuzin, I.P., 2005. Seismicity and Tsunamis in the Northeastern Part of the Black Sea. Oceanology, 45(6), pp. 791-794.

15. Grigorash, Z.K. and Korneva, L.A., 1972. Mareograficheskie Dannye o Tsunami v Chernom More pri Turetskom Zemletryasenii v Dekabre 1939 goda [Mareographic Data on the Tsuna$\mathrm{mi}$ in the Black Sea during the Turkish Earthquake in December 1939]. Oceanology, 12(3), pp. 417-422 (in Russian).

16. Kaz'min, V.G., Lobkovskii, L.I. and Pustovitenko, B.G., 2004. Present-Day Microplate Kinematics in the Black Sea-South Caspian Region. Oceanology, 44(4), pp. 564-573.

17. Chebanenko, I.I., Gozhik, P.F., Evdoshchuk, N.I. and Klochko, V.P., 2003. Skhema Glubinnykh Razlomov na Uchastkakh Krymskogo i Kavkazskogo Poberezhiy Chernogo Morya [Scheme of Deep Faults on the Crimean and Caucasian Black Sea Coast Sections]. Ecologichnyi Zhurnal, [e-journal] (1), pp. 54-58. Available at: http://ashipunov.info/jurassic/j/crimea/06/Chebanenko.et.al.2003.pdf [Accessed 20 May 2016] (in Russian).

18. Garagash, I.A. and Lobkovskii, L.I., 2000. Geomekhanicheskaya Otsenka Opolznevykh Protsessov i Ikh Monitoring na Sklonakh Chernogo Morya v Svyazi s Realizatsiey Proekta “Goluboy Potok" [Geomechanical Assessment of Landslide Processes and their Monitoring on the Slopes of the Black Sea in Connection with the Implementation of the Blue Stream

PHYSICAL OCEANOGRAPHY NO.3 (2017) 
Project]. In: Materialy VI Mezhdunarodnoj Nauchno-Tekhnicheskoj Konferencii "Sovremennye Metody i Sredstva Okeanologicheskikh Issledovaniy" [Proc. $6^{\text {th }}$ International ScientificTechnical Conference "Modern Methods and Means of Oceanological Research"]. Moscow: Institute of Oceanology RAS, pp. 5-15 (in Russian).

19. Yolsal-Çevikbilen, S. and Taymaz, T., 2012. Earthquake Source Parameters along the Hellenic Subduction Zone and Numerical Simulations of Historical Tsunamis in the Eastern Mediterranean. Tectonophysics, [e-journal] 536-537, pp. 61-100. doi:10.1016/j.tecto.2012.02.019

20. Lobkovskii, L.I., Mazova, R.Kh. and Kolchina, E.A., 2014. Otsenki Maksimal'nykh Vysot Voln Tsunami dlya Poberezh'ya Goroda Sochi pri Vozmozhnykh Sil'nykh Podvodnykh Zemletryaseniyakh [Estimates of the Maximum Tsunami Wave Heights for the Sochi Coast under Possible Strong Underwater Earthquakes]. Doklady Akademii Nauk, 456(5), pp. 604-609 (in Russian).

21. Mazova, R.Kh. and Tresvyatskaya, E.A., 2006. Numerical Modeling of the Generation of Long Waves by a Dynamic Seismic Source and their Propagation in the Black Sea. Russ. J. Earth Sci., [e-journal] 8(6), pp. ES6003. doi:10.2205/2006ES000212

22. Lobkovskii, L.I., Mazova, R.Kh. and Kolchina, E.A., 2009. Maksimal'nye Vysoty Voln Tsunami na Sochinskom Poberezh'e pri Vozmozhnykh Sil'nykh Podvodnykh Zemletryaseniyakh [Maximum Heights of Tsunami Waves on the Sochi Coast with Possible Strong Underwater Earthquakes]. Mining Informational and Analytical Bulletin (scientific and technical journal) , 18(12), pp. 16-21 (in Russian)

23. Fomicheva, L.A., Rabinovich, A.B. and Demidov, A.N., 1991. Tsunami v Chernom More [Tsunami in the Black Sea]. In: Gidrometeorologiya i Gidrokhimiya Morey SSSR. Vol. 4. Chernoe More, Issue 1. Gidrometeorologicheskie Issledovaniya [Hydrometeorology and Hydrochemistry of the USSR Seas. T. IV. The Black Sea. Vol. 1. Hydrometeorological Studies]. Saint Petersburg: Gidrometeoizdat, pp. 352-354 (in Russian).

24. Zaitsev, A.I., Kurkin, A.A., Polukhina, O.E., Samarina, N.M. and Yalchiner, A.C., 2003. Chislennoe Modelirovanie Vozmozhnykh Opolznevykh Tsunami v Chernom More [Numerical Modeling of Possible Landslide Tsunami in the Black Sea]. News Academy of Engineering Sciences A.M. Prokhorov. Prikladnaya Mathematics i Physics, (4), pp. 150-154 (in Russian).

25. Zaitsev, A.I. and Pelinovsky, E.N., 2011. Forecasting of Tsunami Wave Heights at the Russian Coast of the Black Sea. Oceanology, [e-journal] 51(6), pp. 907-915. doi:10.1134/S0001437011050225

26. Gazprom Export, 2016. TurkSream. [online] Available at: http://www.gazpromexport.ru/en/projects/6/ [Accessed 28 May 2016].

27. South Stream, 2016. World Class Expertise. [online] Available at: http://www.south-streamtransport.com/ [Accessed 20 May 2016].

28. Wells, D.L. and Coppersmith, K.J., 1994. New Empirical Relationships among Magnitude, Rupture Length, Rupture Width, Rupture Area and Surface Displacement. Bulletin of the Seismological Society of America, [e-journal] 84(4), pp. 974-1002. Available at: http://seismo.berkeley.edu/ rallen/teaching/eps256-s07/WellsCoppersmith1994.pdf [Accessed 20 May 2016].

29. Lobkovskii, L.I. and Baranov, B.V., 1984. Klavishnaya Model' Sil'nykh Zemletryaseniy v Ostrovnykh Dugakh i Aktivnykh Kontinental'nykh Okrainakh [The Key Model of Strong Earthquakes in Island Arcs and Active Continental Margins]. Doklady AN SSSR, 275(4), pp. 843-847 (in Russian).

30. Pelinovsky, E.N., 1982. Nelineynaya Dinamika Voln Tsunami [Nonlinear Dynamics of Tsunami Waves]. Gorkiy: IPF AN SSSR, 226 p. (in Russian).

31. Sielecki, A. and Wurtele, M.G., 1970. The Numerical Integration of the Nonlinear ShallowWater Equations with Sloping Boundaries. J. Comput. Phys., [e-journal] 6(2), pp. 219-236. doi:10.1016/0021-9991(70)90022-7 